\title{
SISTEM PENGOLAHAN DATA STATUS TINGKATAN SISWA TAPAK SUCI PUTERA MUHAMMADIYAH PIMDA 07 KABUPATEN MAGELANG BERBASIS WEB
}

\author{
Wildan Fatkhul Barry ${ }^{1}$, Mukhtar Hanafi ${ }^{2}$, Endah Ratna Arumi ${ }^{3}$ \\ Program Studi S1 Teknik Informatika, Universitas Muhammadiyah Magelang \\ Fakultas Teknik Informatika, Universitas Muhammadiyah Magelang
}

\section{Informasi Makalah}

Dikirim, 5 Agustus 2019

Direvisi,

Diterima, 30 April 2021

\section{Kata Kunci:}

Pimda

Tapak suci

Pengolahan data

Tersentral

\section{Keyword:}

Pimda

Tapak suci

Data processing

Centered

\begin{abstract}
INTISARI
Pimda 07 Tapak Suci Kabupaten Magelang tidak memiliki semua data siswa tapak suci disetiap cabang/unit latihan, hal ini dikarenakan pendataan siswa tapak suci dilakukan secara berulang pada pelaksanaan ujian kenaikan tingkat. Oleh sebab itu dibutuhkan sebuah sistem untuk mengetahui data siswa tapak suci sesuai tingkatan maupun keseluruhan dari semua cabang/unit latihan yang ada di kabupaten magelang. Sistem ini dirancang menggunakan bahasa pemrograman PHP, database MySQL dan Framework CodeIgniter. Penelitian ini menghasilkan sistem pengolahan data siswa tapak suci yang tersentral pada sistem berbasis web sehingga Pimda 07 Tapak Suci Kabupaten Magelang dapat mengetahi keseluruhan data siswa tapak suci berdasarkan grafik dan membuat laporan dalam format (.xlsx). Pengujian usability dengan hasil $85.62 \%$ dan dikonversikan kedalam skala kualitatif didapat hasil sangat layak dan memenuhi aspek usability.
\end{abstract}

\begin{abstract}
Pimda 07 Tapak Suci Magelang regency did not have the data of Tapak Suci students in each branch / training unit, this is since the student data collection of Tapak Suci students was carried out repeatedly along with the test of improvement level. Therefore, a system was needed to collect the data of Tapak Suci student based on levels and on the whole branches / training units in Magelang Regency. This system was designed by using the PHP programming language, MySQL database and CodeIgniter Framework. This study resulted in a data processing system for Tapak Suci students, which is centered on a web-based system, so that Pimda 07 Tapak Suci Magelang Regency can access all student data based on charts and make reports in the (.xlsx) format. Usability test was done with the result of $85.62 \%$ and was converted into qualitative scale. The result said that it was very reasonable and met the aspect of usability.
\end{abstract}

\section{Korespondensi Penulis:}

Wildan Fatkhul Barry

Program Studi S1 Teknik Informatika

Universitas Muhammadiyah Magelang

Jl. Mayjend. Bambang Soegeng, Mertoyudan, Magelang 56172

Email: wildanfb7@gmail.com 


\section{PENDAHULUAN}

Peran sistem informasi terhadap kemajuan organisasi sudah tidak diragukan, dengan dukungan sistem informasi yang baik maka telah banyak organisasi yang memanfaatan sistem informasi untuk mengorganisir pengelolaan informasi sehingga tidak mengalami keterlambatan penyampaian informasi. Oleh karena itu teknologi informasi berperan sebagai alat bantu untuk memudahkan pengelolaan suatu sumber daya yang dimiliki oleh suatu organisasi, sehingga saat ini anggota dalam organisasi dituntut untuk dapat menggunakan teknologi [1][2].

Tapak Suci merupakan salah satu Organisasi Otonom Muhammadiyah untuk pembinaan mental dan pengkaderan yang telah berkembang berdirinya Pimpinan Daerah (PIMDA) tapak suci di seluruh wilayah Indonesia[3]. Pimpinan Daerah Tapak Suci berkedudukan di setiap kabupaten/kota sebagai pelaksana administrasi dan bertindak secara operasional. Untuk melancarkan tugas operasional, Pimpinan Daerah dapat mendirikan cabang Tapak Suci di daerahnya[4].

Berdasarkan keterangan dari sekretaris PIMDA 07 Kabupaten Magelang Muhwan Hariri, PMa, saat ini telah banyak berdiri cabang/unit latihan Tapak Suci di Kabupaten Magelang. Setiap sekolah Muhammadiyah yang ada di Kabupaten dan Kota Magelang diwajibkan untuk menambah extrakulikuler Tapak Suci, sehingga setiap tahun akan semakin bertambah banyak siswa sebagai anggota Tapak Suci. Terdapat 52 cabang/unit latihan di PIMDA 07 Tapak Suci Kabupaten Magelang yang belum dapat mengelola pendataan siswa Tapak Suci. Dengan banyaknya cabang/unit latihan yang ada, PIMDA tidak mengetahui jumlah siswa sesuai tingkatan secara pasti. Setiap siswa pada cabang/unit latihan bisa mengikuti Ujian Kenaikan Tingkat (UKT), dalam jangka waktu minimal 6 (enam) bulan sekali. Terdapat 5 tingkatan siswa tapak suci yaitu, siswa tingkat dasar, siswa satu, siswa dua, siswa tiga, dan siswa empat. Dalam pelaksanaannya, pendataan dilakukan oleh masing-masing kader/pelatih disetiap unit latihan yang dilatih, sehingga data siswa Tapak Suci belum bisa tersentral dari semua unit latihan yang ada di Kabupaten Magelang. Pendataan di cabang/unit latihan belum terkontrol oleh PIMDA, pengadaan UKT masih dilakukan manual dengan siswa mengisi blangko dan mengumpulkan ijazah/ akte kelahiran siswa secara hardfile untuk mengetahui data siswa yang mengikuti UKT, hal tersebut tentu kurang efektif karena data tidak terkontrol dengan baik. Selain kurangnya integrasi data, kesulitan mengelola dan mencari data membutuhkan waktu yang lama bila data tersebut dibutuhkan[5].

Penelitian yang membahas tentang pengelolaan data dan pendataan peserta pada bidang olahraga juga telah banyak dilakukan. Erlianti Putri, Suryatiningsih [6], menyatakan proses pendaftaran ujian kenaikan tingkat setiap periodenya masih dilakukan secara manual, yaitu dengan mengisi formulir pendaftaran. Melihat permasalahan tersebut maka dibuat "Aplikasi Pengolahan Data Anggota dan Informasi Kegiatan Taekwondo Indonesia Kota Cimahi Berbasis Web". Metode yang digunakan untuk membangun aplikasi ini adalah metode Prototype. Bahasa pemrograman yang digunakan yaitu PHP. Database yang digunakan adalah MySQL. Dengan adanya aplikasi ini diharapkan dapat menangani permasalahan dalam melakukan pendaftaran ujian kenaikan tingkat dan penyampaian informasi kegiatan Taekwondo yang akan dilaksanakan di wilayah Kota Cimahi.

Penelitian yang dilakukan oleh Recky dkk. [2], menyatakan kegiatan akademik di SMA Kristen 1 Tomohon meliputi proses memasukkan data pegawai, guru dan data siswa, proses memasukkan data jadwal mata pelajaran, proses memasukkan nilai ujian serta rekapan raport siswa, maka perlu dibangun sebuah sistem informasi berbasis Web yang dapat mempermudah proses akses data tersebut pada database guna mendapatkan informasi yang tepat dan akurat dalam pengaksesan datanya. Dengan menggunakan metodologi Waterfall, perancangan sistem informasi akademik berbasis web ini dapat meningkatkan kualitas pengolahan data akademik di sekolah tersebut. Dengan menggunakan PHP dan MySQL aplikasi ini dapat dirancang dengan mudah. Sistem Informasi Akademik Sekolah Berbasis WEB pada SMA Kristen 1 Tomohon dapat menghasilkan informasi akademik yang lebih akurat dalam hal pengolahan, pencarian informasi data siswa, guru, dan nilai akademik siswa. Aplikasi ini memiliki batasan akses yaitu hanya dapat digunakan oleh siswa-siswi dan guru yang ada di SMA Kristen 1 Tomohon.

Penelitian yang dilakukan oleh Bangun [7], menyatakan bahwa Komite Olahraga Nasional medan harus memiliki sebuah Sistem untuk melakukan pendataan terhadap atlet-atlet junior dan atlet senior. Melihat cara kerja yang dilakukan di Komite Olahraga Nasional yang masih menggunakan Microsoft Excel sebagai penyimpanan data, pendataan akan sulit dilakukan dan data yang diperoleh belum tentu akurat. Pengembanggan sistem informasi yang didalamnya meliputi proses pengolahan data atlet diharapkan dapat membantu para pencari bakat. Sistem ini dikembangkan berbasis Dektop dengan Implementasi system informasi ni menggunakan bahasa pemograman Visual Basic Net 2008. Untuk database management sistem-nya menggunakan MySQL.

Dari referensi penelitian yang ada disimpulkan bahwa penggunaan sistem berbasis Web terbukti efektif dalam pengelolaan data. Penelitian yang dilakukan ini akan memanfaatan sistem berbasis Web dengan bahasa pemrograman PHP dan database MySql dapat mempermudah pengolahan data sehingga 
data bisa tersentralisai secara online dari masing-masing cabang/unit latihan yang ada di Kabupaten Magelang. Dengan dibangunya sistem pengolahan data Siswa Tapak Suci Kabupaten Magelang sesuai tiga referensi yang ada diharapkan dapat memberikan kemudahan untuk mengelola data Siswa Tapak Suci sesuai tingkatan, pendataan UKT dan penilaian hasil UKT. Adanya sistem pengelolaan data dapat dikelola lebih mudah walaupun terjadi perubahan personal[8].

\section{METODOLOGI PENELITIAN}

\subsection{Flowchart Sistem}

Dengan memanfaatkan teknologi yang semakin berkembang, maka penelitian ini akan fokus untuk membuat sebuah sistem berbasis web yang dapat mengolah data siswa Tapak Suci di Kabupaten Magelang. Pendataan dilakukan oleh masing-masing kader/pelatih disetiap unit latihan yang dilatih, sehingga data siswa Tapak Suci bisa tersentral dari semua unit latihan yang ada di Kabupaten Magelang.

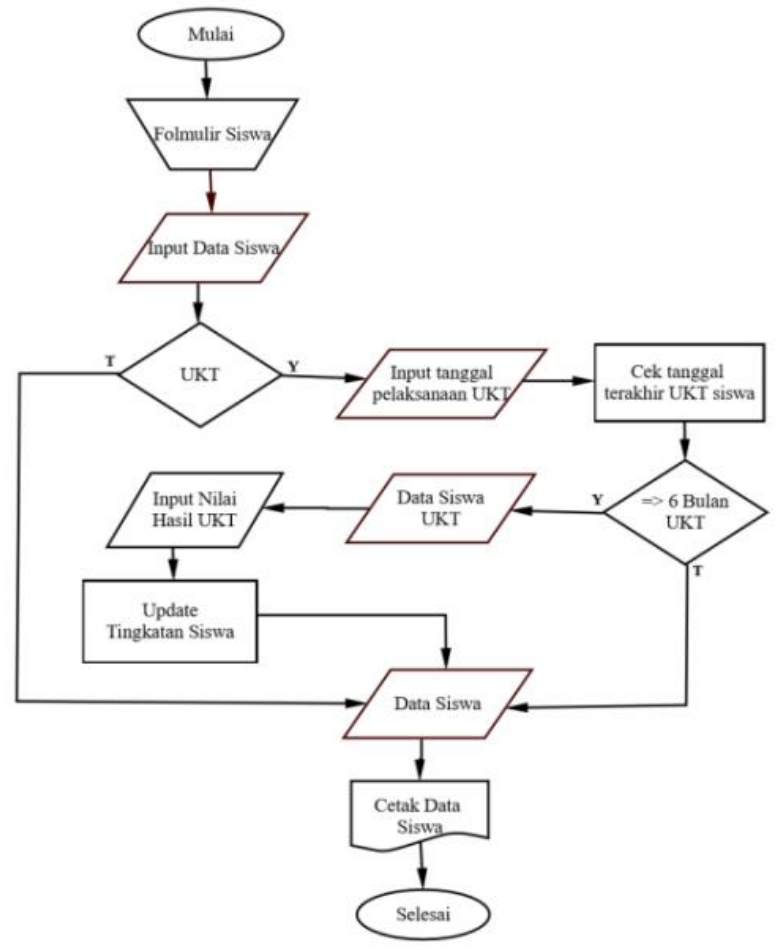

Gambar 1. Flowchart sistem

Gambar 1. flowchart menjelaskan tentang alur sistem yang akan dibuat. Pelatih menginputkan data siswa ke sistem dan jika ada pelaksanaan UKT, penguji menginputkan tanggal pelaksanaan UKT untuk mengetahui data siswa UKT sesuai ketentuan. Penguji dapat melihat data siswa yang megikuti UKT berdasarkan hasil data yang dimasukan, dan penguji memasukan nilai hasil UKT. Sistem akan mengupdate tingkatan siswa dari nilai yang dimasukan oleh penguji jika memenuhi kriteria penilaian. Menurut Muhwan Hariri, PMa siswa dengan jumlah nilai minimal 325 bisa lulus/naik status tingkatanya. ada lima penilaian yang diambil yaitu, Al-Islam Kemuhammadiyahan, Ilmu Pencak Silat, Keorganisasian, Fisik dan Mental Bela Diri.

a. Perancangan Sistem

Perencanaan sistem kerja software ini digambarkan dengan standar Unified Modeling Language (UML) karena memiliki konsep berorientasi objek dan banyak digunakan digunakan untuk merancang sistem.[9] UML yang digunakan meliputi: Use case dan Class diagram. 
1) Use Case Diagram

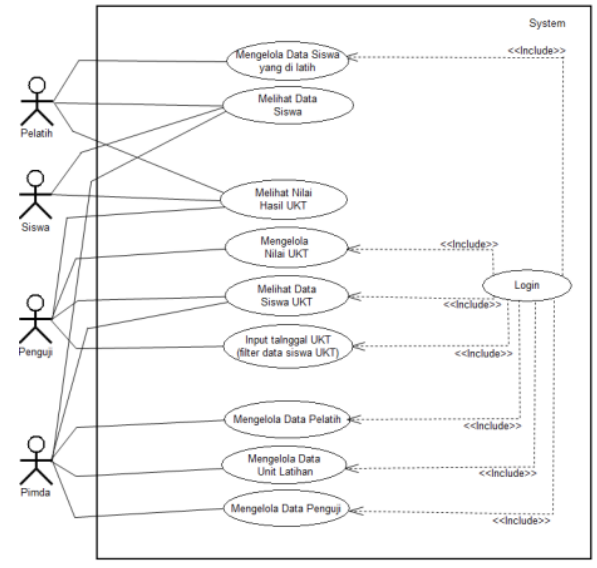

Gambar 2. Use Case Diagram

Gambar 2. Use Case Diagram menunjukan ada empat aktor yang berperan dalam sistem yaitu pelatih, siswa, penguji, dan Pimda. Actor siswa hanya bias melihat data pada sistem tanpa memerlukan login, sedangkan pelatih, penguji dan pimda harus login sebelum menggunakan sistem. Pelatih berperan untuk menginput data siswa yang dilatih disetiap unit latihan. Penguji berperan mengolah data siswa UKT. Pimda berperan mengelola data pelatih dan data penguji.

2) Activity Diagram

Activity Diagram dapat dilihat pada Gambar 3. menunjukan aktifitas yang terjadi pada pengolahan data siswa menggunakan sistem. Aktifitas pertama yaitu pelatih menginputkan data siswa dari masing-masing unit latihan yang dilatih. Penguji menginputkan tanggal pelaksanaan UKT untuk mengetahui data siswa yang bisa mengikuti UKT sesuai ketentuan. Penguji menginputkan nilai siswa yang mengikuti UKT dan sistem akan mengupdate status tingkatan siswa berdasarkan hasil nilai yang diinputkan. Pimda mendapatkan data siswa yang tersimpan disistem untuk dibuat laporan.

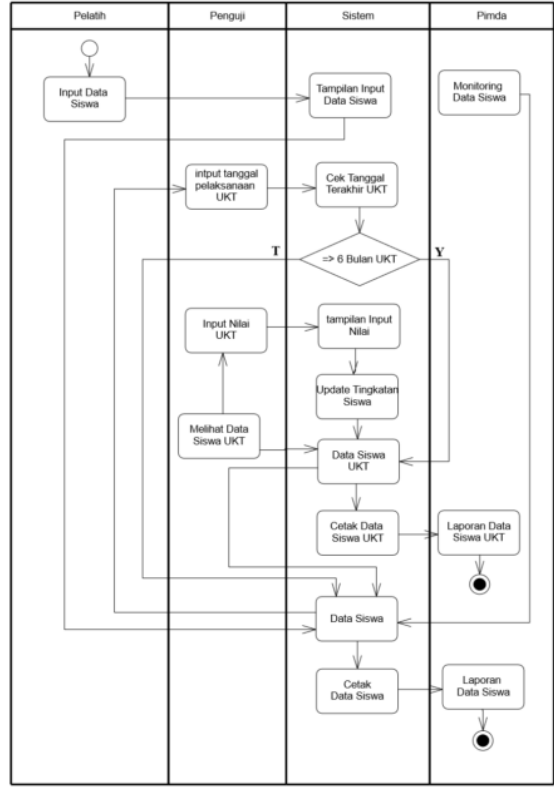

Gambar 3. Activity Diagram 
b. Perancangan database

Entity Relationship Diagram (ERD) adalah diagram umum, yang bertujuan untuk membentuk konsep relasi database. [10]

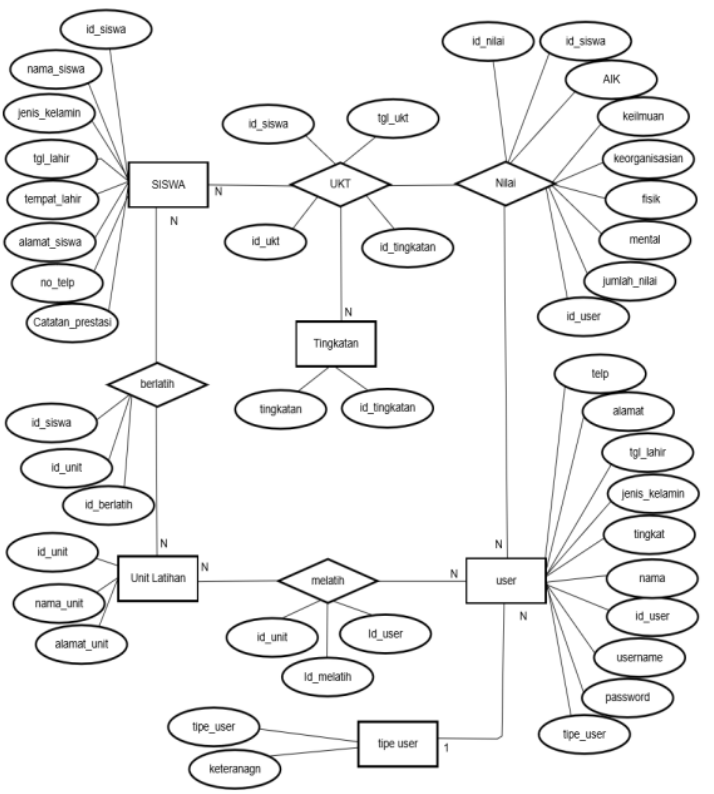

Gambar 4. Entity Relationship Diagram

Gambar 4. menunjukan gambar ERD pada database, siswa dan tingkatan memiliki kardinalitas $\mathrm{N}: \mathrm{N}$ dan menghasilkan table hasil relasi yaitu ukt dengan id penghubung id_siswa dan id_tingkatan, siswa dan unit latihan memiliki kardinalitas N:N dan menghasilkan table hasil relasi yaitu berlatih dengan id penghubung id_siswa dan id_unit, ukt dan user memiliki kardinalitas N:N dengan id penghubung id_siswa dan id_user sebagai foreign key yang menghasilkan table nilai, unit latihan dan user memiliki kardinalitas $\mathrm{N}: \mathrm{N}$ dan menghasilkan table hasil relasi yaitu melatih dengan id penghubung id_unit dan id_user, user dan tipe_user memiliki kardinalitas N:1 dengan tipe_user sebagai foreign key pada table user.

c. Perancangan Interface

User interface adalah desain dari komputer, peralatan, mesin, perangkat komunikasi seluler, aplikasi perangkat lunak, dan situs web dengan berfokus pada desain halaman web untuk menghubungkan pengguna dan isi web.[11]

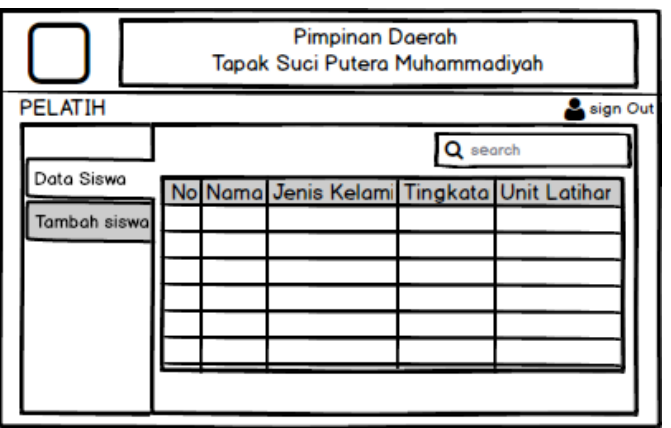

Gambar 5. Tampilan Akses Pelatih

Gambar 5. menunjukan rancangan tampilan akses pelatih pada sistem untuk mengelolah data siswa. 


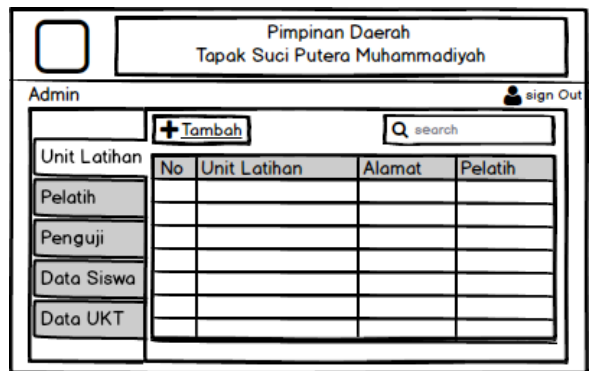

Gambar 6. Tampilan Akses Pimda

Gambar 6. menunjukan rancangan tampilan akses pimda untuk mengelola data unit latihan, pelatih dan penguji pada sistem.

\section{HASIL DAN PEMBAHASAN}

Hasil dari pengujian program yang dilakukan menentukan apakah hasil yang diharapkan sesuai output dari sistem. Pengujian yang digunakan adalah pengujian functionality menggunakan metode blackbox yang berfokus pada persyaratan fungsional yaitu digunakan untuk menentukan fungsi yang tidak benar atau tidak ada, kesalahan antarmuka, kesalahan struktur data dan pengujian aspek usability menggunakan instrument berupa angket untuk mengetahi apakah sistem bisa diterima oleh user. Jika saat pengujian sistem yang dibuat dan dirancang terjadi ketidaksesuaian maka akan dilakuakan maintenance.

Sistem pengolahan data siswa Tapak Suci berbasis web dapat digunakan siswa, pelatih, penguji dan pimda. Sumber data siswa Tapak Suci dari pelatih yang memasukan data ditiap unit latihan dan tersimpan tersentral pada sistem. Penguji mengolah data UKT siswa berdasarkan data yang telah dimasukan dari tiap unit latihan. Sedangkan siswa dapat melihat informasi data status tingkatannya.

Dengan data siswa yang sudah tersentral pada sistem, pimda dapat mengetahui jumlah siswa yang aktif, jumlah siswa berdasarkan tingkatanya, jumlah siswa dimasing-masing unit latihan, jumlah siswa dipelaksanaan UKT dari sistem dan dapat mencetak file dengan tipe data (.xlsx) Microsoft Excel. Berdasarkan hasil pengujian, terdapat beberapa output yang didapatkan dari sistem. Berikut merupakan pembahasan dari setiap hasil pengujian yang telah dilakukan.

\section{a. Mempermudah Pencarian Data Siswa}

Pengujian yang dilakuakn mulai dari pelatih memasukan data siswa Tapak Suci berdasarkan Unit Latihan. Dari data tersebut, siswa, pelatih dan pimda dapat mencari data siswa pada kolom pencarian dengan memasukan kata kuncinya. Berikut Gambar 7. menampilkan data siswa yang dicari berdasarkan kata kunci yang dimasukan pada kolom pencarian.

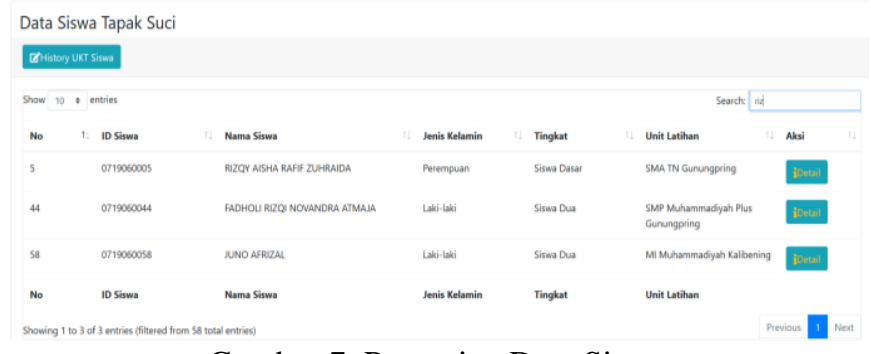

Gambar 7. Pencarian Data Siswa

Jika siswa sudah pernah mengikuti ujian kenaikan tingkat, siswa dapat melihat history UKT dengan mencari dan memasukan nama siswa tersebut. Berikut Gambar 8. merupakan form pencarian history UKT.

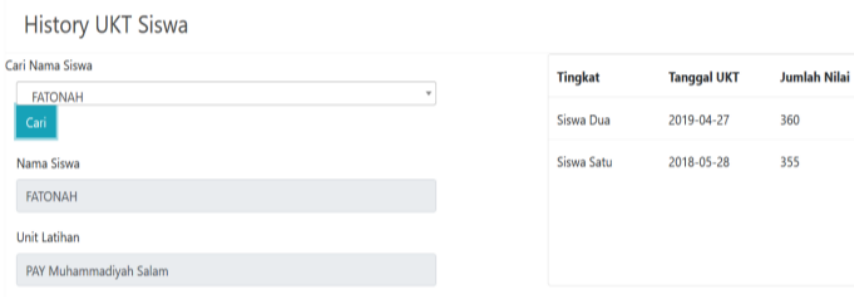

Gambar 8. Pencarian Data UKT Siswa 
b. Mempermudah Pimda dalam Pembuatan Laporan

Pada pengujian ini dilakukan dengan memasukan rentang waktu untuk membuat laporan data siswa, data siswa berdasarkan tingkatan dan data siswa berdasarkan unit latihan. Untuk memonitoring jumlah data siswa tapak suci dan membuat laporan data UKT siswa dengan cara mencari dan memasukan tanggal pelaksanaan UKT kemudian menekan tombol print maka sistem secara otomatis akan mengunduh file laporan dengan format (.xlsx).

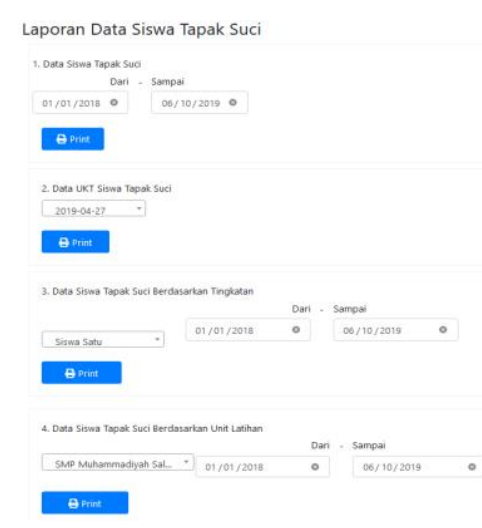

Gambar 9. Form Cetak Laporan

Gambar 9. merupakan halaman form cetak laporan, laporan data siswa tapak suci, data UKT siswa tapak suci, data siswa berdasarkan tingkatanya dan data siswa berdasarkan unit latihannya.

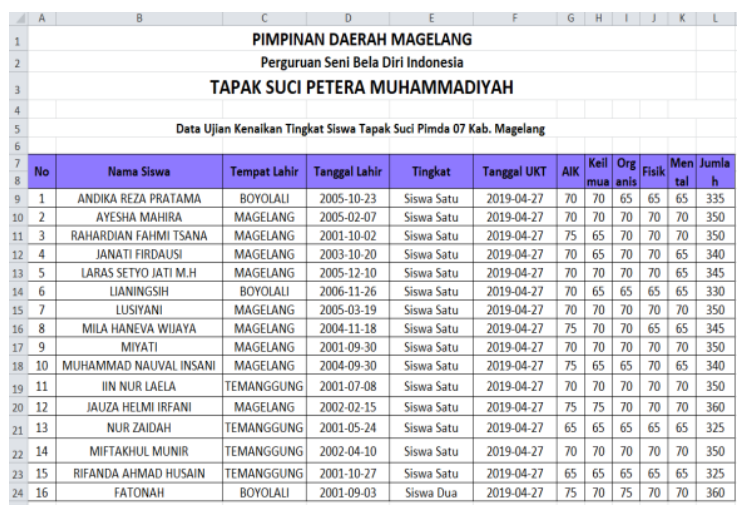

Gambar 10. Laporan Data UKT Siswa

Gambar 10. merupakan hasil laporan data ujian kenaikan tingkat siswa berdasarkan tanggal UKT dengan format (.xlsx).

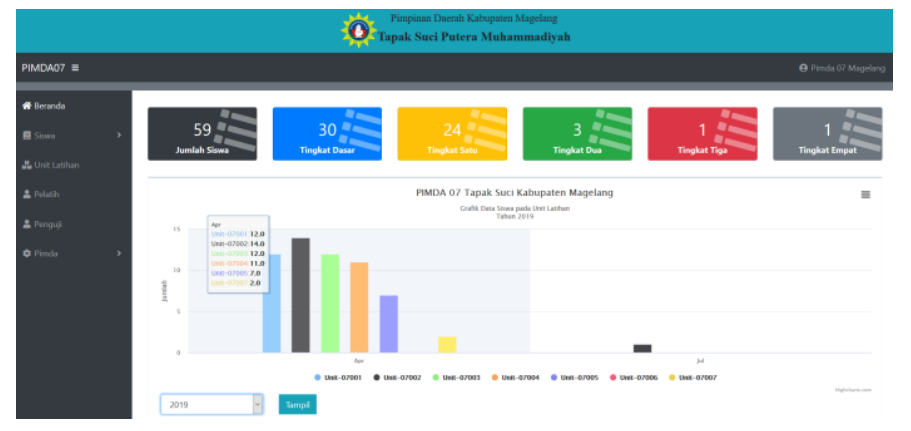

Gambar 11. Tampilan Grafik Data Siswa Tapak Suci

Gambar 11. merupakan tampilan monitoring jumlah data siswa secara keseluruhan maupun sesuai ketingkatan dari semua unit latihan yang ditampilkan tahun terakhir siswa UKT. 
c. Pengujian Functionality

Pengujian menggunakan metode Black Box yang berfokus pada persyaratan fungsional yaitu digunakan untuk menentukan fungsi yang tidak benar atau tidak ada, kesalahan antarmuka, kesalahan struktur data dan sebagainya. Pengujian berdasarkan aktor yang berperan dalam sistem yaitu siswa, pelatih, penguji dan pimda.

Pengujian yang dilakukan oleh PIMDA tentang penggunaan login, menu Data Siswa, Data UKT, Laporan, Unit Latihan, Pelatih, dan Penguji mendapatkan hasil valid. Pengujian yang dilakukan oleh Pelatih tentang penggunaan login, menu Data Siswa dan Tambah Siswa mendapatkan hasil valid. Pengujian yang dilakukan oleh Penguji tentang penggunaan login, menu Ujian Kenaikan Tingkat dan Nilai mendapatkan hasil valid. Pengujian yang dilakukan oleh Siswa tentang penggunaan menu Home, Data Siswa, dan Unit Latihan mendapatkan Hasil valid.

d. Pengujian Usability

Hasil pengujian usability dilakukan menggunakan kuesioner yang diberikan ke siswa, pelatih, penguji, dan Pimda 07 Tapak Suci Kabupaten Magelang untuk mengetahi apakah sistem bisa diterima oleh user dengan hasil presentase sebagai berikut :

\begin{tabular}{cll}
\multicolumn{3}{c}{ Table 1. Hasil Pengujian Usability } \\
\hline No & Responden & Presentase \\
\hline 1 & Siswa & $82.5 \%$ \\
2 & Pelatih & $90.18 \%$ \\
3 & Penguji & $86.15 \%$ \\
4 & Pimda & $83.64 \%$ \\
Rata-rata & $85.62 \%$ \\
\hline
\end{tabular}

Rata-rata presentase hasil pengujian usability adalah $85.62 \%$ dan dikonversikan kedalam skala kualitatif sehingga didapat hasil "Sangat Layak" dan memenuhi aspek usability.

Sistem ini dilengkapi feature validasi pada inputan, nama harus berisi huruf tidak bolah ada angka dan nomor telepon harus berisi angka tidak boleh ada huruf yang inputkn untuk menghindari kesalahan input data.

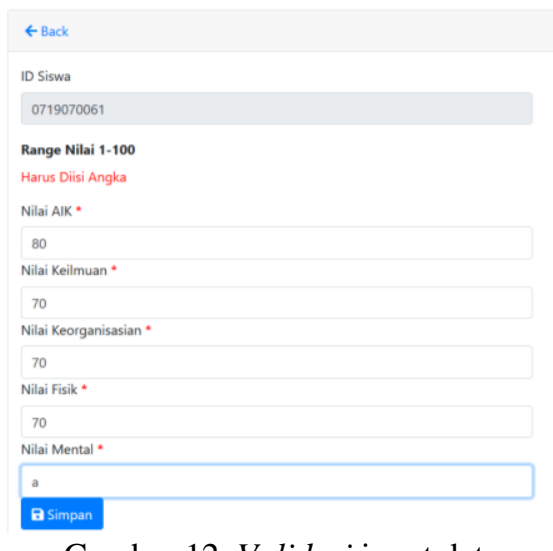

Gambar 12. Validasi input data

Dari hasil pengujian yang telah dilakukan, secara garis besar sistem berjalan dengan baik sesuai kebutukan PIMDA 07 Tapak Suci kabupaten Magelang. Sistem ini dapan mempermudah pencarian data siswa tapak suci dan memudahkan dalam pembuatan laporan dengan cepat jika sewaktu-waktu laporan dibutuhkan.

Techno Vol. 22, No. 2, Oktober 2021: $131-140$ 
1) Kelebihan

Kelebihan sistem pendataa siswa tapak suci ini adalah dapat memonitoring jumlah siswa aktif di Pimda 07 Tapak Suci Kabupaten Magelang tiap tahunnya berdasarkan siswa yang mengikuti ujian kenailan tingkat (UKT). pada pelaksanaan UKT data tidak perlu melakukan pendataan ulang, data berdasarkan dari masing-masing cabang/unit latihan yang diinpukan oleh pelatih.

2) Kekurangan

Sistem ini hanya mensentralkan data siswa tapak suci dari semua unit latihan yang ada di Kabupaten Magelang dan menampilkan informasi data siswa tapak suci saja, untuk mengakses sistem ini masih terbatas berdasarkan data yang dikelola oleh Pimda.

\section{KESIMPULAN}

Dari hasil pembahasan yang sudah diuraikan penulis dapat mengambil kesimpulan sebagai berikut :

a. Sistem pengolahan data siswa Tapak Suci dapan mempermudah pelatih dalam menyimpan data siswa Tapak Suci dimasing-masing Unit Latihan dan data tersimpan tersentral pada sistem sehingga Pimda 07 Tapak Suci kabupaten Magelang dapat mengetahui keseluruhan data siswa Tapak Suci yang ada di Kabupaten Magelang dalam bentuk grafik maupun laporan dengan format (.xlsx).

b. Pengujian usability dengan hasil rata-rata $85.62 \%$ dan dikonversikan kedalam skala kualitatif sehingga didapat hasil "Sangat Layak" dan memenuhi aspek usability.

\section{DAFTAR PUSTAKA}

[1] K. Nasikin, "Pengembangan Sistem Informasi Akademis Dan Keuangan Di Man 2 Pati," J. Speed - Sentra Penelit. Eng. dan Edukasi - ijns.org, vol. 3, no. 3, pp. 20-26, 2011.

[2] M. Recky T. Djaelangkara, Rizal Sengkey, ST., MT, Oktavian A. LAntang, ST, "Perancangan Sistem Informasi Akademik Sekolah Berbasis Web Studi Kasus Sekolah Menengah Atas Kristen 1 Tomohon," 2015.

[3] R. B. Ma'arif, "Peran Extrakurikuler beladiri Tapak Suci Putra Muhammadiyah Dalam Menanamkan Sikap Rendah Hati Pada Siswa SMA Muhammadiyah Mlati sleman Yogyakarta," UNIVERSITAS ISLAM NEGERI SUNAN KALIJAGA YOGYAKARTA, 2014.

[4] muhammadiyah.or.id, "Tapak Suci," 1997. [Online]. Available: http://www.muhammadiyah.or.id/content-86-dettapak-suci.html. [Accessed: 30-Sep-2018].

[5] M. Purba, "Sistem informasi sekolah menengah kejuruan (SMK) Teknologi Informasi dan Bisnis Indosains Palembang Berbaris Web," J. Inform., vol. 1, no. 2, pp. 31-42, 2015.

[6] W. M. Erlianti Putri, Suryatiningsih, "Web-Based Application of Members Data Processing and Activities," vol. 3, no. 3, pp. 1472-1480, 2017.

[7] B. Bangun, "SISTEM INFORMASI PENDATAAN ATLET PADA KOMITE OLAHRAGA NASIONAL ( KONI ) MEDAN," J. INFOTEK, vol. 3, no. 1, 2018.

[8] I. G. Novita Br Ginting, Hersanto Fajri, "Penerapan Knowledge Management System pada Pengelolaan Data Organisasi Kemahasiswaan," Penerapan Knowl. Manag. Syst. pada Pengelolaan Data Organ. Kemahasiswaan Univ. Ibn Khaldun Bogor, vol. 02, no. 2, pp. 30-36, 2014.

[9] A. B. Charef and H. Djamila, "Users Integrity Constraints in SOLAP Systems . Application in Agroforestry," pp. 47-56, 2018.

[10] A. Susanto and N. B. Mulyono, "Information Management of Web Application Based Environmental Performance Management in Concentrating Division of PTFI," vol. 12001, 2018.

[11] C. Hsu, "The Visual Web User Interface Design in Augmented Reality Technology," vol. 4, no. 2, pp. 116-121, 2013. 
